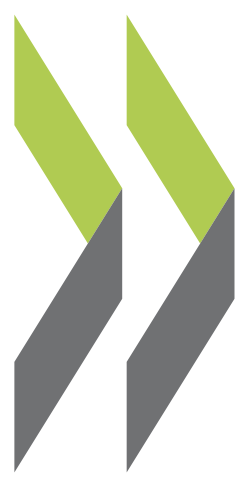

OECD Economics Department Working Papers No. 1350

\author{
The Ins and Outs \\ of Employment in 25 OECD \\ Countries
}

Paula Garda 
Organisation de Coopération et de Développement Économiques

Organisation for Economic Co-operation and Development

28-Nov-2016

ECONOMICS DEPARTMENT

English - Or. English

THE INS AND OUTS OF EMPLOYMENT IN 25 OECD COUNTRIES

ECONOMICS DEPARTMENT WORKING PAPERS No. 1350

By Paula Garda

OECD Working Papers should not be reported as representing the official views of the OECD or of its member countries. The opinions expressed and arguments employed are those of the author(s).

Authorised for publication by Christian Kastrop, Director, Policy Studies Branch, Economics Department.

All Economics Department Working Papers are available at www.oecd.org/eco/workingpapers.

JT03406355

Complete document available on OLIS in its original format

This document and any map included herein are without prejudice to the status of or sovereignty over any territory, to the delimitation of international frontiers and boundaries and to the name of any territory, city or area. 
OECD Working Papers should not be reported as representing the official views of the OECD or of its member countries. The opinions expressed and arguments employed are those of the author(s).

Working Papers describe preliminary results or research in progress by the author(s) and are published to stimulate discussion on a broad range of issues on which the OECD works.

Comments on Working Papers are welcomed, and may be sent to OECD Economics Department, 2 rue André Pascal, 75775 Paris Cedex 16, France, or by e-mail to eco.contact@oecd.org.

All Economics Department Working Papers are available at www.oecd.org/eco/workingpapers.

This paper is part of an OECD project on the consequences of flexibility-enhancing reforms for workers. Other outputs from this project include:

Cournède, B., O. Denk, P. Garda and P. Hoeller (2016), "Enhancing Economic Flexibility: What Is in it for Workers?", OECD Economic Policy Paper, No. 19, OECD Publishing.

Cournède, B., O. Denk and P. Garda (2016), "Effects of Flexibility-Enhancing Reforms on Employment Transitions", OECD Economics Department Working Papers, No. 1350, OECD Publishing.

Denk, O. (2016), "How Do Product Market Regulations Affect Workers? Evidence from the Network Industries", OECD Economics Department Working Papers, No. 1349, OECD Publishing.

This document and any map included herein are without prejudice to the status of or sovereignty over any territory, to the delimitation of international frontiers and boundaries and to the name of any territory, city or area.

Latvia was not an OECD Member at the time of preparation of this publication. Accordingly, Latvia does not appear in the list of OECD Members and is not included in the zone aggregates.

\section{(C) OECD (2016)}

You can copy, download or print OECD content for your own use, and you can include excerpts from OECD publications, databases and multimedia products in your own documents, presentations, blogs, websites and teaching materials, provided that suitable acknowledgment of OECD as source and copyright owner is given. All requests for commercial use and translation rights should be submitted to rights@oecd.org 


\section{ABSTRACT/RÉSUMÉ \\ The ins and outs of employment in 25 OECD countries}

This paper presents quantitative information on labour market flows for 25 OECD countries. It uses household surveys that offer the advantage of reporting monthly transitions between employment, unemployment and economic inactivity for individuals. Between 2005 and 2012, the annual probability of leaving employment averaged $10 \%$ across OECD countries. Jobless people have a $30 \%$ average probability of finding a job. The analysis uncovers significant cross-country differences and highlights key facts about how labour market flows differ depending on socio-demographic, worker characteristics and the institutional framework. Female, young, low educated and low income workers are at highest risk of becoming jobless. Young jobless individuals have higher chances of finding a job than their older counterparts. Female, low educated and low income jobless individuals face a lower probability of finding a job than others.

JEL Classification: J23 ; J62 ; J63 ; J82

Keywords: labour market, employment transitions, unemployment, skills, socio-economic inequality

\section{Les transitions professionnelles dans 25 pays de l'OCDe}

Cet article présente des données quantitatives concernant les flux de main-d'œuvre sur le marché du travail dans 25 pays de l'OCDE. Les enquêtes sur lesquelles il repose présentent l'avantage de fournir des informations mensuelles sur les transitions entre emploi, chômage et inactivité au niveau individuel. Entre 2005 et 2012, la probabilité annuelle de quitter son emploi était en moyenne de $10 \%$ dans l'ensemble de la zone OCDE, tandis que la probabilité moyenne de trouver un emploi s'établissait à $30 \%$. L'analyse met en évidence des différences importantes entre les pays et décrit les grandes évolutions des flux de maind'œuvre sur le marché du travail en fonction des caractéristiques sociodémographiques et professionnelles des travailleurs ainsi que du cadre institutionnel. Elle révèle ainsi que les femmes, les jeunes, les moins qualifiés et les travailleurs à faible revenu sont les catégories les plus exposées au risque de perdre son emploi, que les jeunes sans emploi ont davantage de chances de trouver du travail que leurs homologues plus âgés, et que, parmi les personnes sans emploi, les femmes, les travailleurs peu qualifiés et les travailleurs à bas revenu présentent une moindre probabilité de retour à l'emploi.

Classification JEL : J23 ; J62 ; J63 ; J82

Mots clés : marché du travail, transitions professionnelles, chômage, qualifications, inégalités socioéconomiques. 


\section{TABLE OF CONTENTS}

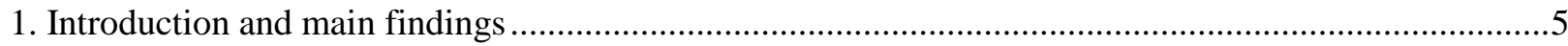

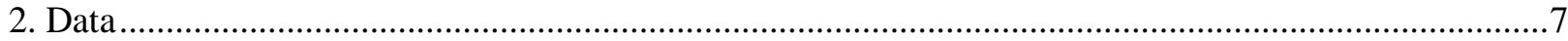

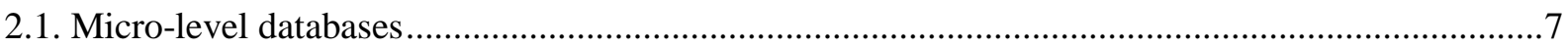

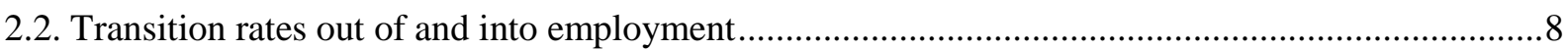

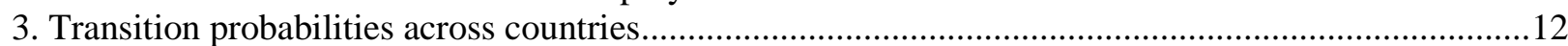

4. The heterogeneity of the transition probabilities across individuals ...................................................16

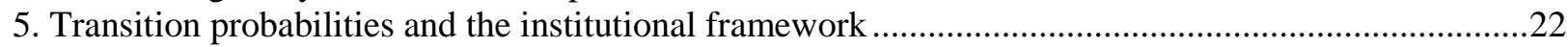

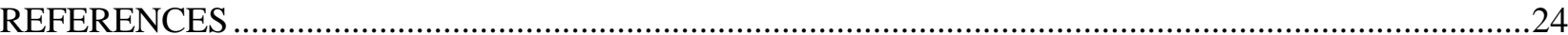

\section{Tables}

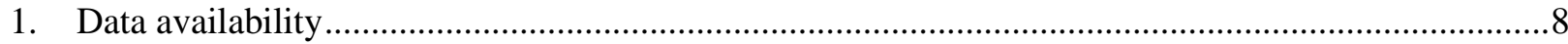

2. The variation of labour market flows over the business cycle...................................................15

\section{Figures}

1. The flow-based employment rate is very close to the observed employment rate ...........................11

2. Employment rates in labour force surveys versus household surveys ............................................11

3. Cross-country differences in transition probabilities are large .........................................................12

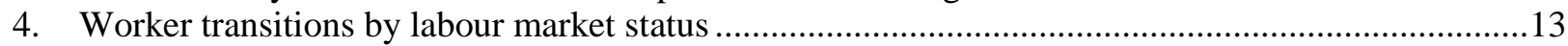

5. In most countries unemployment transitions are higher than inactivity transitions ..........................14

6. A high probability of becoming employed goes hand in hand with high job-to-job transitions .........16

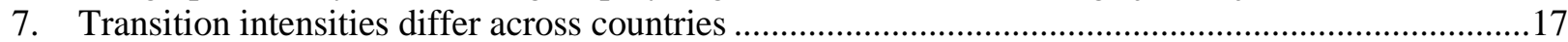

8. High transition rates are observed for male, low education and young workers ..............................18

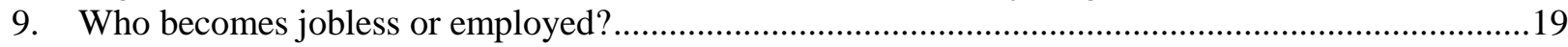

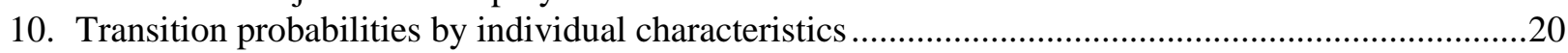

11. Women are nearly four times more likely than men to become economically inactive ....................21

12. Policies differ between countries with high and low transitions probabilities ..................................22

\section{Box}

Box 1. Linking the transition probabilities to the employment rate 10 
ECO/WKP(2016)74

\title{
THE INS AND OUTS OF EMPLOYMENT IN 25 OECD COUNTRIES
}

\author{
By Paula Garda ${ }^{1}$
}

\section{Introduction and main findings}

1. This paper describes the ins and outs of employment across countries for different sociodemographic groups of workers. ${ }^{2}$ The empirical analysis of the labour market has long concentrated on understanding the determinants of employment and unemployment levels (see for example, Gal and Theising, 2015; Bassanini and Duval, 2009; Murtin et al., 2014). However, analysing individual workers' ins and outs of employment and their frequency is important from a welfare perspective. Unemployment spells lower well-being for individuals and their families, because they involve earnings losses (see for example, Couch and Placzek, 2010; Davis and von Wachter, 2011), generate economic insecurity (Venn, 2011), can compromise labour market prospects and even hurt health (Sullivan and von Wachter, 2009). While transitions into unemployment have negative effects on well-being, transitions into employment have a positive impact on life satisfaction, since they reduce unemployment duration (Hijzen and Menyhert, 2016). Previous OECD work has analysed stylised facts of worker and job-flows using firm level data (OECD, 2009) and the impact of policies and institutions on these worker flows (Bassanini et al., 2010; OECD, 2010). Other research has also used Labour Force Surveys (LFS) to investigate the impact of employment protection on worker flows (Bassanini and Garnero, 2013).

2. Not all job losses, however, involve financial loss or substantial hardship for individuals and their families. Indeed, high labour market transition rates could reflect the capacity for constant renewal, career development and productivity-enhancing reallocation of jobs. Indeed, for a given unemployment rate, high unemployment turnover has been found to increase life satisfaction (Hijzen and Menyhert, 2016).

3. While transitions from employment to unemployment are in general involuntary job losses, some transitions to inactivity might be voluntary and temporary, such as among young people still engaged in education or training or women who are caring for family members. These types of transitions do not necessarily reduce workers' well-being.

1. Economics Department, OECD. Email: Paula.Garda@oecd.org. The author would like to thank Andrea Bassanini (Employment, Labour and Social Affairs Directorate), Boris Cournède, Oliver Denk, Peter Hoeller, Christian Kastrop, Catherine L. Mann, Jean-Luc Schneider, Christine Lewis and Mikkel Hermansen (Economics Directorate) for their comments. Special thanks go to Celia Rutkoski for editorial assistance. The opinions expressed and arguments employed are those of the authors and should not be reported as representing the official views of the OECD or its member countries.

2. This paper forms part of an OECD project looking at worker-level consequences of flexibility-enhancing reforms. Cournède et al. (2016a) presents the main findings of the project and discusses policy implications. A companion paper reports findings from micro-level work about how deregulation of network industries influences the working lives of workers employed in these industries Denk (2016). Cournède, Denk and Garda (2016b) analyse how reforms that make product markets or employment protection more flexible influence individual workers' transitions in and out of employment. 
4. The main contribution of this paper is to present quantitative information on labour market flows for 25 OECD countries. It uses household surveys that have the advantage of reporting monthly transitions between employment, unemployment and being out of the labour force for individuals. The study analyses transitions between employment, unemployment and being out of the labour force. The paper highlights key facts about how labour market flows differ depending on socio-demographic and worker characteristics. Evidence is presented about how labour market flows vary across workers depending on age, gender, highest attained education level and position in the labour income distribution. Finally, the paper analyses institutional characteristics of countries with low and high worker flows.

5. The main findings are:

- Between 2005 and 2012, the annual probability of becoming jobless (defined as unemployed or economically inactive) averaged $10 \%$ across OECD countries. Jobless people have a $30 \%$ average probability of finding a job. Significant cross-country differences underlie these averages. Many workers move from employment to joblessness and vice versa in Austria, Finland, Portugal, Spain and Sweden. Labour market transitions are relatively infrequent in Belgium, the Czech Republic, France, Luxembourg, Poland, the Slovak Republic and Slovenia.

- The majority of workers who change status do so just once. Nevertheless, $18 \%$ of workers moving between employment and joblessness do so twice or more. Such unstable employment relationships, which appear to be an inherent feature of many OECD labour markets, are likely to be particularly harmful to people's well-being.

- OECD averages also hide significant heterogeneity across individuals. Several common patterns emerge across countries. Young workers have a twice higher risk of leaving their job than older workers, but they also have a higher probability of finding a job when out of employment. This higher rotation rate is likely to be related to young workers trying to find the best match for their career development but also to a more intensive use of fixed-term contracts.

- Female, low educated and low income workers face the highest risk of becoming jobless. Once jobless, these groups of workers experience lower probabilities of moving into a job. This means that labour market insecurity is particularly high for these groups of workers with consequent detrimental effects on individuals' well-being. The size of the effects implies that lacking education, alone, can increase one's labour market insecurity several times relative to their higheducated peers.

- The large cross-country variation in the out of and into employment transition probabilities suggests that national policies and institutions may shape the patterns of worker flows in OECD countries. Countries with very rigid labour and product markets are characterised by low transition probabilities in and out of employment. By contrast, unemployment benefit generosity and high spending on active labour market policies are associated with high transition probabilities.

6. The next section presents the data and the transition variables used in the analysis. Section 3 compares transition probabilities across OECD countries, while section 4 analyses how transition probabilities differ across socio-demographic and worker characteristics. Section 5 analyses the policy environments that characterise low and high transition probability countries. 


\section{Data}

\subsection{Micro-level databases}

7. Longitudinal panel household surveys provide a rich basis for studying individual labour market outcomes. This work drew on household surveys to build a database harmonising micro-level data across 25 OECD countries.

8. Two micro panels provide information on individual characteristics, labour market participation and earnings across European countries:

- The European Community Household Panel (ECHP) covers 15 European OECD countries from 1994 to 2001. The ECHP follows individuals over time.

- The European Union Statistics on Income and Living Conditions (EU-SILC) covers 23 European OECD countries from 2003 to 2012. Participants rotate quickly in EU-SILC: individuals are replaced within four years in most countries.

9. These panels are complemented with household surveys for three OECD countries: Australia (HILDA, 2001-12), Germany (SOEP, 1994-2012) and Switzerland (SHP, 1999-2013). For Germany, the study uses the national SOEP survey instead of ECHP and EU-SILC, because Germany is not present in the longitudinal files of EU-SILC. For the United Kingdom, EU-SILC and ECHP are used instead of BHSP and UKHLS, which do not provide monthly information about labour market status. Other household surveys (PSID for the United States and KLIPS for Korea) have also been explored. However, they lack variables needed to calculate transition probabilities.

10. The final dataset represents a large panel of workers aged between 25 and 59 years in 25 OECD countries (Table 1). The dataset is restricted to workers aged 25 to 59 to minimise the effect on the measured outcomes of students who take up work and workers who retire.

11. This dataset has strengths and weaknesses. An important strength is that it provides monthly information about whether people are working, unemployed or economically inactive during the income reference period. This high frequency allows observing labour market transitions in and out of employment at a high level of detail, including for people who alternate between short-term jobs, unemployment and economic inactivity. Another source of strength is that the dataset contains individual-level information about income, which makes it possible to look at differences in outcomes depending on where people stand in the income distribution. By contrast, a limitation of the dataset is that it comprises substantially fewer observations than labour force surveys. Data from the household surveys rather than the labour force surveys, which is the primary source to calculate labour market statistics, were nonetheless preferred because only the former collects detailed information on the labour market status during the year and offers detailed income information. 
Table 1. Data availability

\begin{tabular}{|c|c|c|c|c|c|c|c|c|c|c|c|c|c|c|c|c|c|c|c|}
\hline & サ & $\begin{array}{l}10 \\
8 \\
\circ \\
\end{array}$ & $\begin{array}{l}0 \\
9 \\
9 \\
\end{array} \mid$ & $\left|\begin{array}{l}\hat{D} \\
\mathscr{8} \\
-\end{array}\right|$ & $\left|\begin{array}{l}\infty \\
\infty \\
\infty \\
\end{array}\right|$ & $\begin{array}{l}9 \\
8 \\
8 \\
\\
\end{array}$ & 용 & 효요 이 & $\begin{array}{l}\text { ऽ } \\
\text { 이 }\end{array}$ & 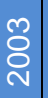 & $\begin{array}{l}\text { ঠ } \\
\text { ঠి }\end{array}$ & 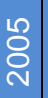 & $\begin{array}{l}\qquad \\
\stackrel{2}{ } \\
\stackrel{2}{ }\end{array}$ & 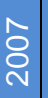 & $\begin{array}{l}\infty \\
\text { ○े } \\
\text { రి }\end{array}$ & 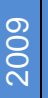 & 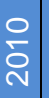 & $\underset{\mathbf{O}}{\mathbf{\sigma}}$ & $\frac{N}{\frac{N}{O}}$ \\
\hline AUS & & & & & & & & & & & & & & & & & & & \\
\hline AUT & & & & & & & & & & & & & & & & & & & \\
\hline $\mathrm{BEL}$ & & & & & & & & & & & & & & & & & & & \\
\hline $\mathrm{CHE}$ & & & & & & & & & & & & & & & & & & & \\
\hline CZE & & & & & & & & & & & & & & & & & & & \\
\hline DEU & & & & & & & & & & & & & & & & & & & \\
\hline DNK & & & & & & & & & & & & & & & & & & & \\
\hline ESP & & & & & & & & & & & & & & & & & & & \\
\hline EST & & & & & & & & & & & & & & & & & & & \\
\hline FIN & & & & & & & & & & & & & & & & & & & \\
\hline FRA & & & & & & & & & & & & & & & & & & & \\
\hline GBR & & & & & & & & & & & & & & & & & & & \\
\hline GRC & & & & & & & & & & & & & & & & & & & \\
\hline HUN & & & & & & & & & & & & & & & & & & & \\
\hline $\mathrm{IRL}$ & & & & & & & & & & & & & & & & & & & \\
\hline ISL & & & & & & & & & & & & & & & & & & & \\
\hline ITA & & & & & & & & & & & & & & & & & & & \\
\hline LUX & & & & & & & & & & & & & & & & & & & \\
\hline NLD & & & & & & & & & & & & & & & & & & & \\
\hline NOR & & & & & & & & & & & & & & & & & & & \\
\hline $\mathrm{POL}$ & & & & & & & & & & & & & & & & & & & \\
\hline PRT & & & & & & & & & & & & & & & & & & & \\
\hline SVK & & & & & & & & & & & & & & & & & & & \\
\hline SVN & & & & & & & & & & & & & & & & & & & \\
\hline SWE & & & & & & & & & & & & & & & & & & & \\
\hline
\end{tabular}

Note: A shaded cell indicates that the dataset includes this country and year. Years indicate the reference income period in the survey. EU-SILC; HILDA; SHP; SOEP are used.

Source: OECD calculations

\subsection{Transition rates out of and into employment}

12. This study focuses on transitions out of and into employment. The other possible state, referred to as joblessness, includes unemployment and economic inactivity. The transition variables are built to meet one objective: measuring the probability of employed workers' becoming jobless and jobless people's chances of getting a job. Furthermore, the transition variables need to be consistent with changes in the employment rate from one year to the next.

\section{Transitions at the individual level}

13. Transitions $f_{t}^{E L}$ and $f_{t}^{L E}$ between employment $\mathrm{E}$ and joblessness $\mathrm{L}$ are defined as follows for individual worker $i$ over the course of year $t$ :

$$
f_{t i}^{E L}=\sum_{m=1}^{12} \delta_{i}^{E L}(m-1, m) \text { and } f_{t i}^{L E}=\sum_{m=1}^{12} \delta_{i}^{L E}(m-1, m)
$$

where $\delta_{i}^{E L}(m-1, m)$ is a dummy variable equal to 1 if individual $i$ is employed in month $m-1$ and jobless in month $m$. The dummy variable $\delta_{i}^{L E}(m-1, m)$ follows a symmetric definition for transitions from joblessness to employment. 
14. After summing transitions over a year, the variable $f_{t}^{E L}$ measures the number of times an employed worker at the end of year $t-1$ experiences a transition into joblessness. This is a discrete variable ranging from 0 , no change in status, to 6 if the worker changed status every month of the year. By using monthly information and summing transitions over the course of the year, this definition captures the experiences of people who undergo short-term employment spells in a detailed fashion. Symmetrically, $f_{t}^{L E}$ measures transitions into employment in a granular way.

\section{The transition probabilities at the country level}

15. These transitions are closely linked with changes in aggregate employment $\left(E_{t}\right.$ at the end of year $t$ ). Variable $E_{t}$ measures employment at the end of year $t$ among people who were already present in the working-age population at the end of year $t-1$, which will be called "stayers". A similarly defined variable $L_{t}$ counts stayers who are jobless at the end of year $t-1$. With these definitions, employment among stayers changes as people move in and out of work:

$$
E_{t}=E_{t-1}+\sum_{i}\left(f_{t i}^{L E}-f_{t i}^{E L}\right)
$$

16. Defining all variables using people who stay from the end of the previous year to the end of the current one offers the benefit of making the variables robust to changes in sample size. This consideration is very important in this study, given that the EU-SILC panel, which is the largest component of the present dataset, involves very fast rotation and often significant changes in sample size from one year to the next.

17. Individual indicator transition variables $f_{t i}^{L E}$ and $f_{t i}^{E L}$ can be aggregated into transition probabilities from employment to joblessness $\lambda_{t}^{E L}$ and the other way around $\lambda_{t}^{L E}$ :

$$
\lambda_{t}^{E L}=\frac{\sum_{i} f_{t i}^{E L}}{E_{t-1}} \text { and } \lambda_{t}^{L E}=\frac{\sum_{i} f_{t i}^{L E}}{L_{t-1}}
$$

Transition probabilities defined in this way are generalised transition probabilities, which could take a maximum value of 6 , if everybody in the working-age population hopped in and out of employment month after month. The name probability has been kept, because at monthly frequency they correspond to probabilities. Furthermore, many people experience no or very few transitions, so that $\lambda_{t}^{E L}$ and $\lambda_{t}^{L E}$ remain well below unity at the aggregate level. Box 1 discusses the link between transition probabilities and the employment rate. 


\section{Box 1. Linking the transition probabilities to the employment rate}

The transition probabilities, $\lambda^{\mathrm{EL}}$ and $\lambda^{\mathrm{LE}}$, defined in (3) are linked to employment changes according to equation (4), which is the result of inserting (3) into (2):

$$
E_{t}-E_{t-1}=\lambda_{t}^{L E} L_{t-1}-\lambda_{t}^{E L} E_{t-1}
$$

This relationship can be rewritten in terms of employment and joblessness rates. These rates $e^{t}$ and $l^{t}$ are defined as ratios with respect to the number of people who belong to the working-age population at the end of year $t-1$. Furthermore, $e^{t}+l^{t}=1$ because people are either employed or not. Consequently, equation (4) by can be rewritten as the following relation between the employment rate and transition probabilities: ${ }^{1}$

$$
\frac{e^{t}-e^{t-1}}{e^{t-1}}=\lambda_{t}^{L E} \frac{1-e^{t-1}}{e^{t-1}}-\lambda_{t}^{E L}
$$

A steady-state interpretation of this relationship provides a way of gauging the employment effects of changes in transition probabilities. Denoting $\hat{e}^{t}=\hat{e}^{t-1}$ the steady-state employment rate compatible with the flows in (5) yields (6) - the flow-based employment rate. Figure 1 shows both measures for every country-year pair in the sample. The comparison indicates that the implied flow-based employment rates $\left(\hat{e}^{t}\right)$ calculated with (6) are very close to the effective employment rates in the sample.

$$
\hat{e}^{t}=\frac{\lambda_{t}^{L E}}{\lambda_{t}^{L E}+\lambda_{t}^{E L}}
$$

The use of steady-state employment rates avoids a complication that arises when interpreting the variables underpinning equations (2-5). The variables in (2-5) have all been defined among people who stay from one year to the next. The employment and joblessness rates in (5) therefore approximate but are not strictly equal to their standard definitions. Standard definitions use the total working-age population, while the employment rates $e^{t}$ and $l^{t}$ are calculated here only among people who stay in the population from one year to the next. Equation (5) therefore measures changes in employment rates imperfectly. A difference can open up between (5) and the true change in employment rates when two conditions are met at the same time: 1) the size of the working age population changes substantially and 2) people entering or exiting the working age population have a systematically different employment status from the stayers. The impact is likely to be small because the two conditions only have a multiplicative impact and the pace of demographic change is slow in OECD countries.

Furthermore, estimates based on the household surveys could differ considerably from those based on labour force surveys. Some of the reasons are: first, following the ILO guidelines, in the labour force surveys persons are classified as employed if during the reference week they worked at least one hour or had a job from which they were temporarily absent during the reference week, while in the household surveys the occupational status at the time of the interview and the calendar variables are instead selfreported, which may lead to underestimate employment, as many people working just a few hours at the time of the interview may not perceive themselves as employed. Indeed, analysing data for the European Union, Brandolini and Viviano (2014) show that employment rates are generally lower in EU-SILC than EU-LFS, though the correlation between both measures is very high (between 0.8 and 0.9 ).

1. Box 1 in Cournède, B., O. Denk and P. Garda (2016b), "Effects of Flexibility-Enhancing Reforms on Employment Transitions", OECD Economics Department Working Papers, No. 1350, OECD Publishing, provides further detail about the derivation. 


\section{Box 1. Linking the transition probabilities to the employment rate (cont.)}

Figure 1. The flow-based employment rate is very close to the observed employment rate

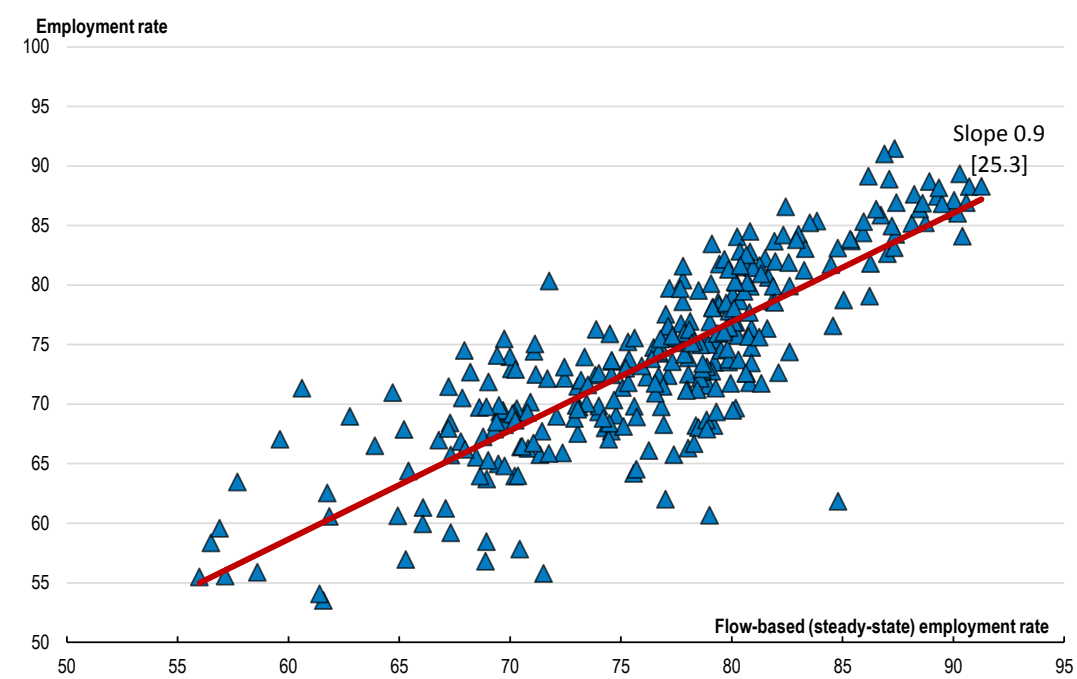

Note: Each point corresponds to a country-year pair between 1994 and 2012. The observed employment rate is calculated within the household surveys for stayers in t and t-1 and people aged between 25 and 59 years old. The flow-based employment rate is calculated according to equation 6 . T-test in parentheses.

Source: OECD Secretariat calculations using ECHP, EU-SILC; HILDA; SHP; SOEP.

The employment rate in the sample, that is defined for stayers aged between 25 and 59 , is on average lower than the employment rate for people aged 25-54 in labour force surveys, but with a very high correlation of 0.8 (Figure 2). The implication is that the flow-based approach using household survey data provides a fairly good approximation of the standard employment rates as measured by labour force surveys.

Figure 2. Employment rates in labour force surveys versus household surveys

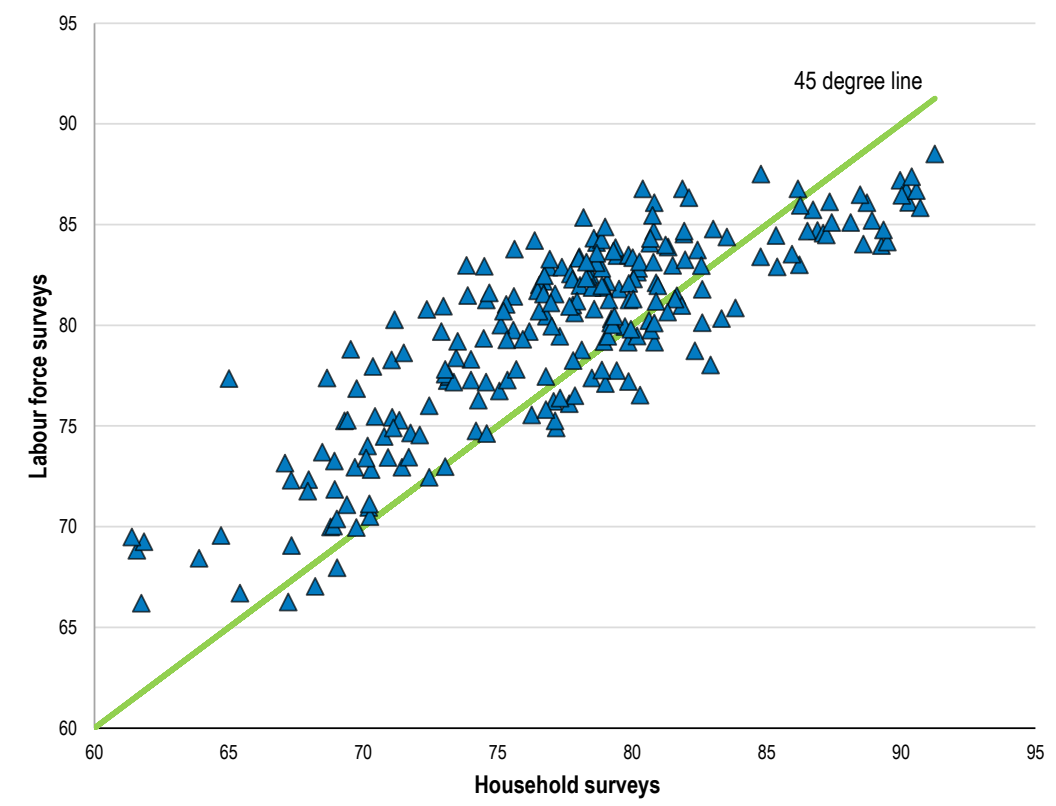

Note: Each point corresponds to a country-year pair in the sample, which covers 25 countries over 1994-2012 (see Table 1 for details on covered countries and years). Employment rates in labour force surveys are for people aged between 25 and 54 years old. Employment rates in household surveys are calculated for stayers in t and $\mathrm{t}-1$ and people aged between 25 and 59 years old. EUSILC; HILDA; SHP; SOEP and OECD Labour Force Statistics are used.

Source: OECD Secretariat calculations. 


\section{Transition probabilities across countries}

18. Figure 3 shows transition probabilities in and out of employment $\left(\lambda^{\mathrm{LE}}\right.$ and $\left.\lambda^{\mathrm{EL}}\right)$ for $25 \mathrm{OECD}$ countries over 2005-12 and for a limited number of countries also over 1994-2001. On average, the annual transition rate from employment to joblessness averages 10\% in OECD countries, while the transition rate into employment is $30 \%$ during $2005-12$. The implied flow-based (steady state) employment rate is $75 \%$ (see Box 1, equation 6, for a description), similar to the standard employment rate from labour force surveys.

19. These flows underline the diversity of OECD labour markets. Every year, many workers in countries such as Austria, Finland, Portugal and Spain move from employment to joblessness and vice versa. On the other hand, labour market transitions reported in Figure 3 are relatively infrequent in Belgium, the Czech Republic, France, Luxembourg, Poland, the Slovak Republic and Slovenia.

Figure 3. Cross-country differences in transition probabilities are large

Percentages
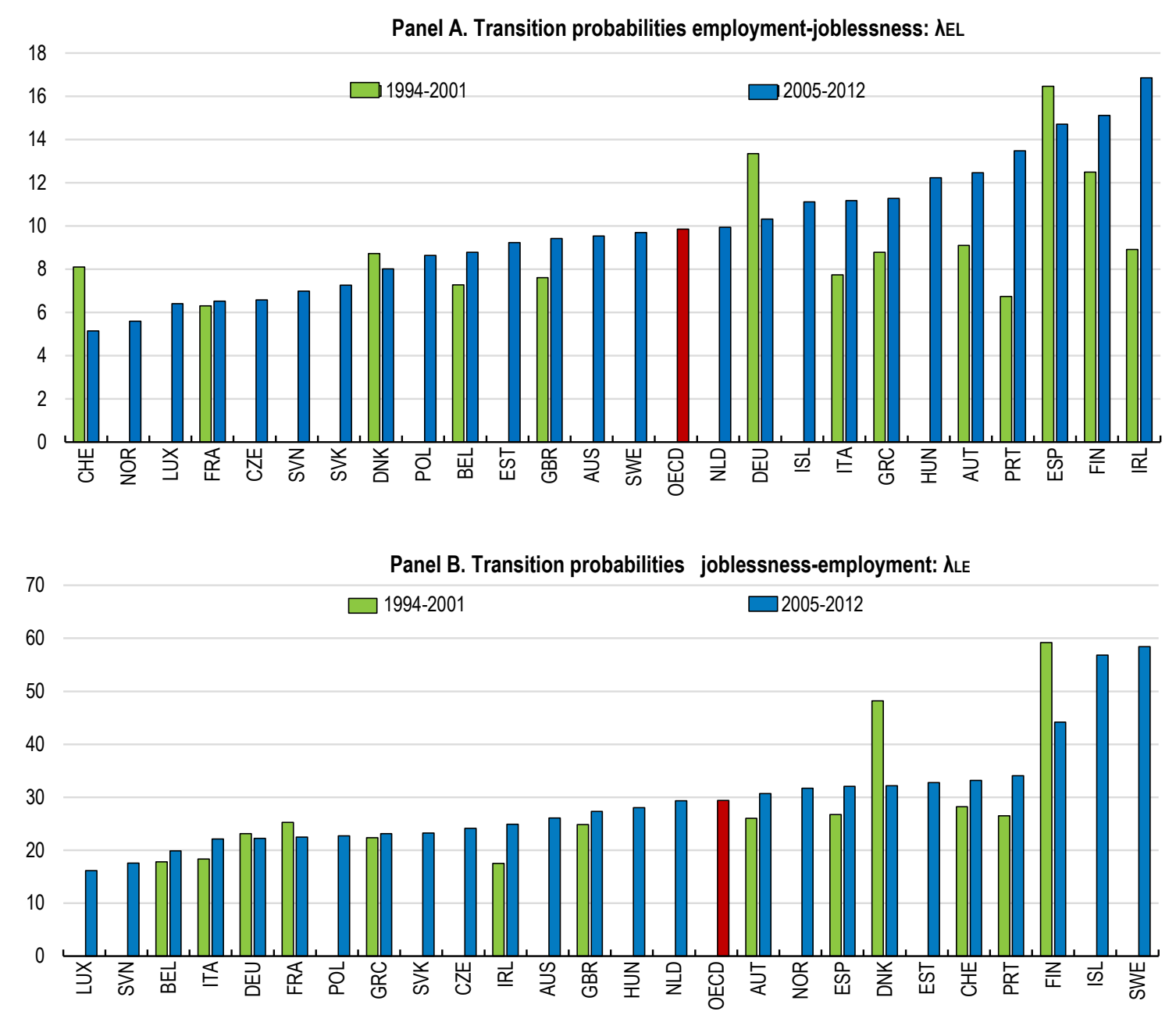

Note: Probability of changing labour market status, conditional on being in the previous status, calculated as in equation 3 . Averages from weighted sample for the periods 1994-2001 and 2005-12 or latest available year. OECD is the simple average for the 25 countries in the sample for the period 2005-12. EU-SILC; HILDA; SHP; SOEP are used.

Source: OECD Secretariat calculations. 
20. Figure 4 decomposes joblessness into unemployment and inactivity and shows average flows into and out of unemployment and inactivity for the OECD countries in the sample. Most employed workers that leave their job move into unemployment. The probability of becoming employed is higher for unemployed workers and averages $46 \%$, while for those inactive during the previous year it averages $20 \%$. The employed becoming jobless have a similar probability of becoming unemployed or inactive. During the period 2005-12 the average flow into unemployment from employment was 5.3\%, while for that into inactivity it was $4.6 \%$. There is an $18 \%$ probability for the unemployed to become inactive, while the probability of becoming inactive from unemployment is $7.5 \%$.

Figure 4. Worker transitions by labour market status

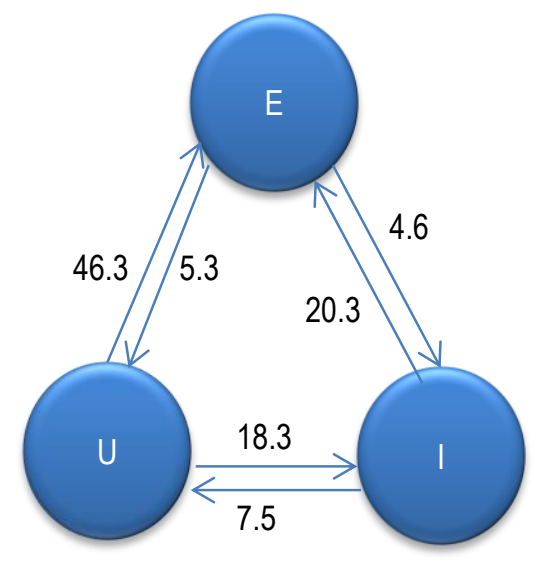

Note: Employment (E); Unemployment (U); Inactivity (I); Probability of changing labour market status, conditional on being in the previous status, calculated as in equation 3. All figures are percentages. Averages are based on the weighted sample for the period 2005-12 or latest available year. See Table 1 for the list of covered countries. EU-SILC; HILDA; SHP; SOEP are used.

Source: OECD Secretariat calculations.

21. Figure 5 analyses the cross-country differences among the flows into and out of unemployment and inactivity. Panel A shows the transition rates from employment to unemployment or inactivity. In most countries the most frequent transition is from employment to unemployment, but there are countries in which moving into inactivity is equally important or even more, such as in Austria, the Slovak Republic and Slovenia. Flows into unemployment are especially high in Spain, Ireland, Portugal and Greece. The high probability for these countries reflects the deep recession at the end of the period under analysis.

22. Panel B illustrates the probability of moving from joblessness (economic inactivity or unemployment) to employment conditional on being jobless at the end of the previous year. These transition rates are particularly high for countries such as Iceland, Norway, Sweden and Switzerland. 
Figure 5. In most countries unemployment transitions are higher than inactivity transitions

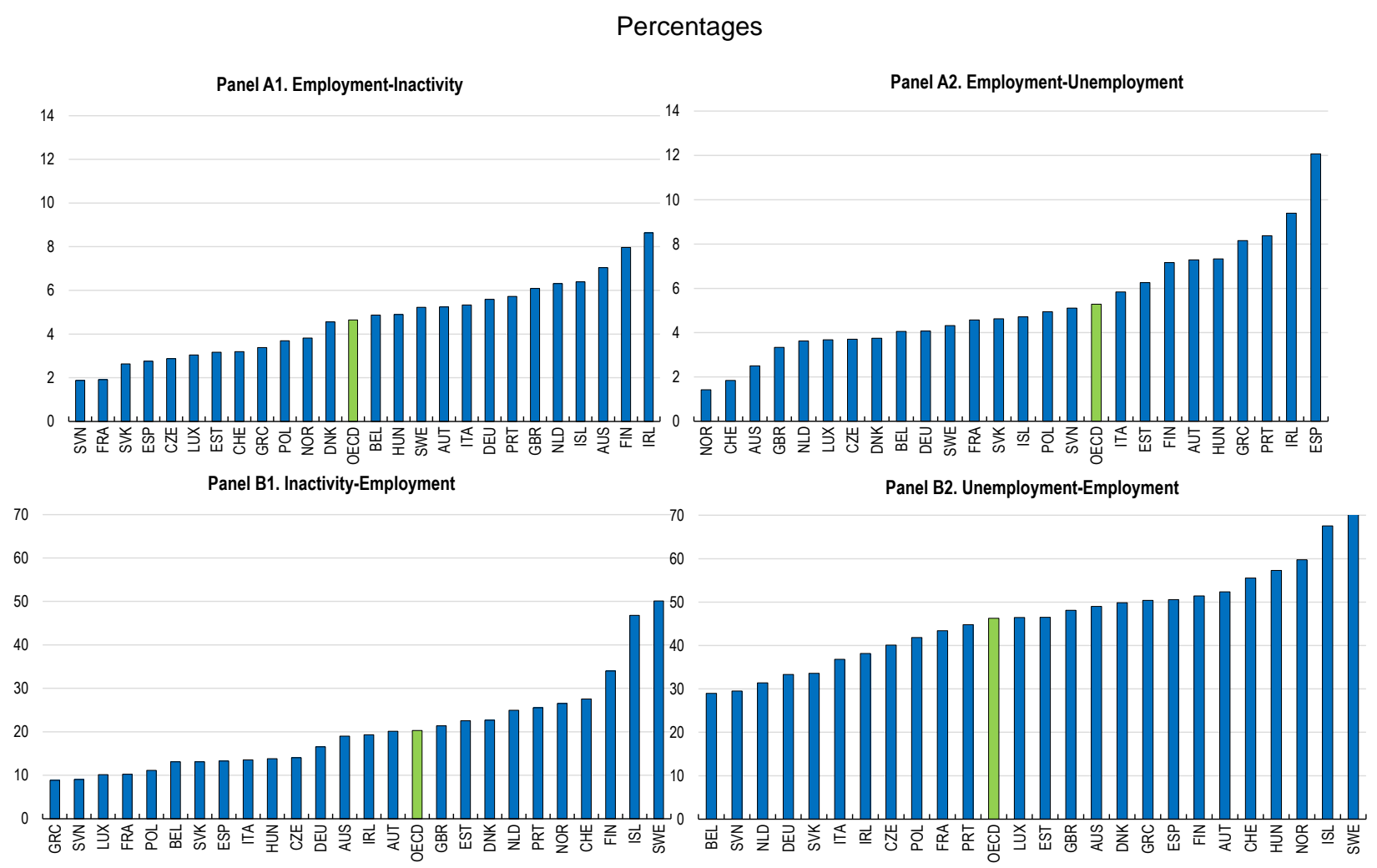

Note: Probability of changing labour market status, conditional on being in the previous status, calculated as in equation 3 . Averages from weighted sample for the period 2005-12 or latest available year. OECD is the simple average for the 25 countries in the sample for the period 2005-12. EU-SILC; HILDA; SHP; SOEP are used.

Source: OECD Secretariat calculations.

23. The extent to which the transitions co-move over the business cycle is critical for the understanding of labour market dynamics and business cycle fluctuations. The cyclicality of the transitions can be measured by their correlation with the level of economic activity, which is estimated by running an ordinary least square regression of the log of each variable on the output gap. The regression adds country fixed effects. The sample is restricted to countries that have data since 1994, so that the time series are long enough to allow estimating business cycle effects. The probability of finding a job is pro-cyclical, coming both from unemployment or economic inactivity (Table 2). Instead, the probability of becoming jobless is counter-cyclical, explained mainly by workers moving into unemployment, while the transition from employment to inactivity is a-cyclical. In economic downturns, as labour market slack increases, the probability of job loss rises, increasing 5.5 percentage points with an increase in the output gap by one percentage point. Moreover, workers see their chance of finding a job drop by 1.1 percentage points. 
Table 2. The variation of labour market flows over the business cycle

\begin{tabular}{ccccccc}
\hline & J--> E & U--> E & I--> E & $E-->J$ & $E->$ U & E--> I \\
\hline \multirow{2}{*}{ Output gap } & $0.011^{*}$ & $0.019^{\star \star \star}$ & $0.022^{\star \star \star}$ & $-0.029^{\star \star \star}$ & $-0.055^{\star \star \star}$ & 0.005 \\
& $(0.006)$ & $(0.007)$ & $(0.008)$ & $(0.007)$ & $(0.008)$ & $(0.010)$ \\
\hline
\end{tabular}

Note: (J) Jobless, (E) Employment, (U) Unemployment, (I) Inactivity. Columns show different transitions, for example $\mathrm{J} \rightarrow \mathrm{E}$ is the transition from Joblessness to Employment. Cyclicality is measured by the coefficient on the output gap in a regression of the transition series in logs on country dummies and the output gap. Sample from 1994-2012 for AUT, BEL, DEU, DNK, ESP, FIN, FRA, GBR, GRC, IRL, ITA and PRT. Standard errors are in brackets. ${ }^{*}$ denotes significant at $1 \%$ and ${ }^{*}$ significant at $5 \%$. EU-SILC; HILDA; SHP; SOEP are used.

Source: OECD Secretariat calculations.

24. Job-to-job flows are also very important for individual welfare and aggregate productivity. Workers tend to build their careers through moving to jobs with higher pay and that last longer. These jobto-job flows translate into enhanced aggregate productivity and earnings gains (Haltiwanger et al., 2015).

25. Household surveys do not allow measuring job-to-job flows directly. However, a rough measure can be obtained by defining them as workers with twelve months in employment during two consecutive years who changed employer since last year. At the country level, this measure provides a lower bound for the job-to-job transition probability, since it does not take into account other types of job-to-job transitions of workers that had also experienced unemployment or had been out of the labour force in one of the two years.

26. The job-to-job transition probability averages $7 \%$ across the 25 OECD countries in the sample. Behind this average there are large cross-country differences: countries such as Norway, Sweden and the United Kingdom have high job-to-job flows of more than 12\% (Figure 6, panel A). At the same time, countries characterised by a high transition rate into employment typically also have high job-to-job flows (Figure 6, panel B). 
Figure 6. A high probability of becoming employed goes hand in hand with high job-to-job transitions

Percentages

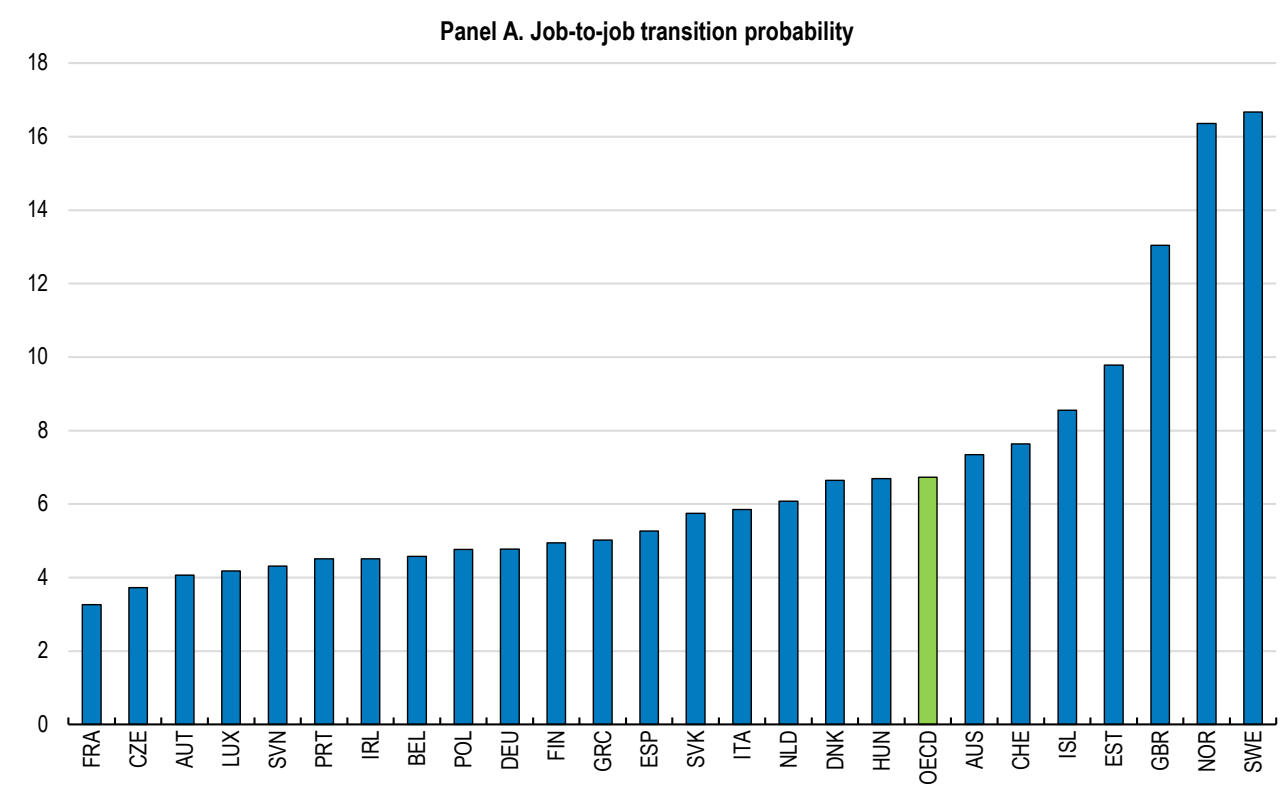

Panel B. Job-to-job flows and the probability of becoming employed

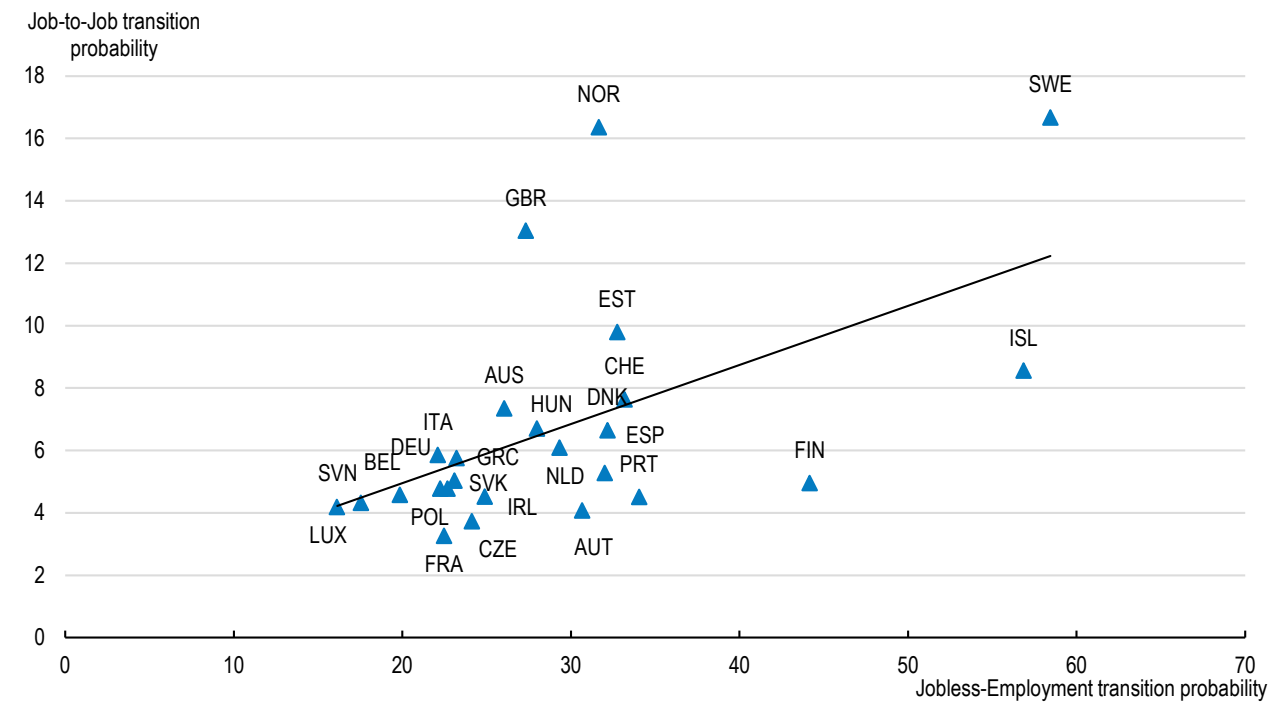

Note: The OECD average in panel A is the simple country average for the period 2005-12 or the latest available year. Panel B reports 2005-12 averages. EU-SILC; HILDA; SHP; SOEP are used.

Source: OECD Secretariat calculations.

\section{Heterogeneity across individuals}

27. At the individual level, the transition probabilities reflect how many times in a year a worker changes status going from employment to joblessness or vice versa, conditional on being employed or jobless, respectively, in December of the previous year. Transitions $f_{t i}^{E L}$ and $f_{t i}^{L E}$ between employment $\mathrm{E}$ and joblessness $\mathrm{L}$ can reach a maximum value of six, if individuals change status every month of the year. Only $0.03 \%$ of the workers showed such a high transition rate. 
28. The majority of workers who change statuses do so just once (Figure 7). However, a significant fraction of workers moves twice or more often between employment and joblessness. Such unstable employment relationships, which appear to be an inherent feature of many OECD labour markets, are likely to be particularly harmful to people's well-being. They are often missed in related studies that usually rely on labour force surveys and therefore do not contain monthly employment information.

Figure 7. Transition intensities differ across countries

Percentages
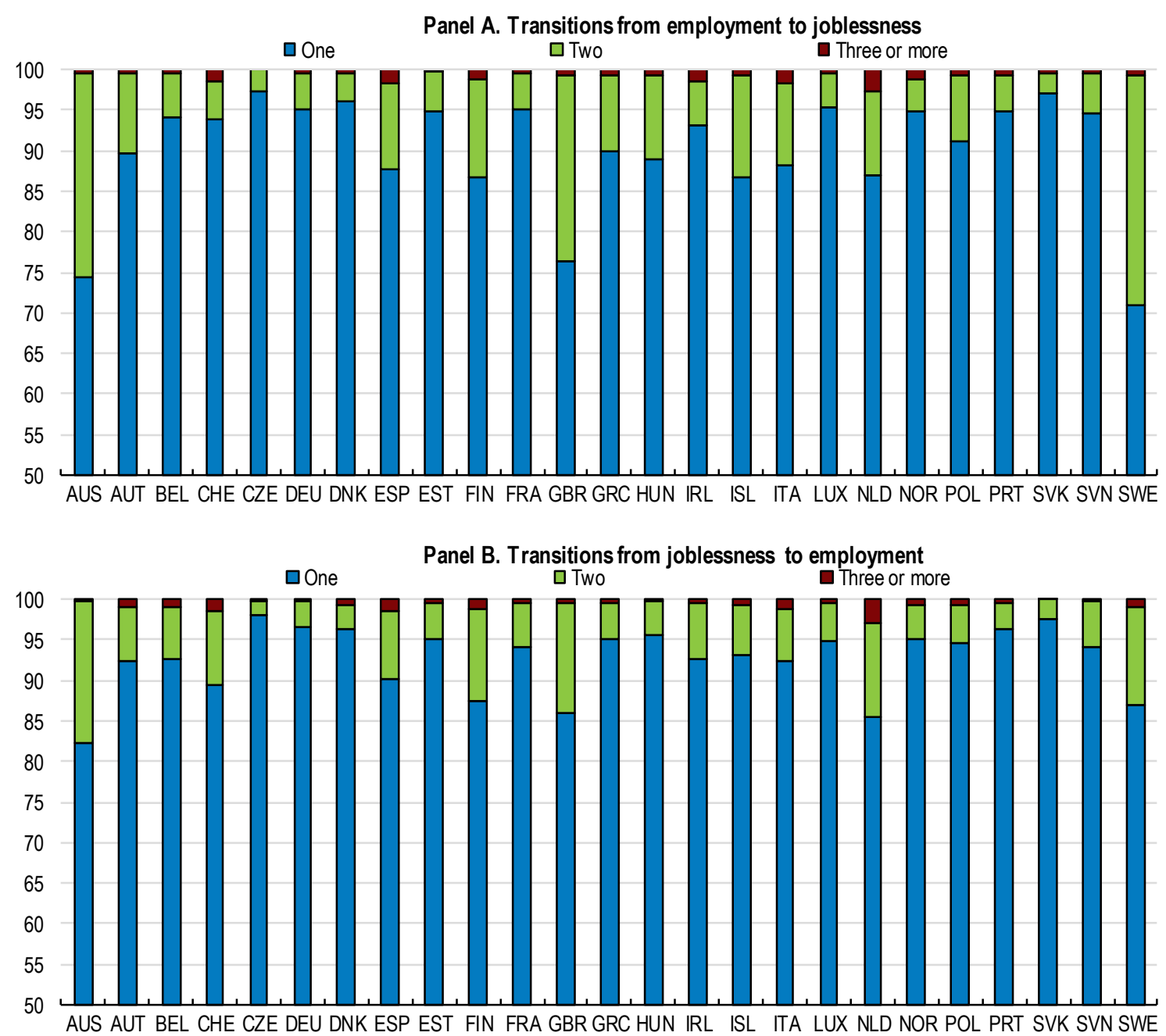

Note: Averages from weighted sample for the period 2005-12 or last year available. EU-SILC; HILDA; SHP; SOEP are used. Source: OECD calculations.

29. The proportion of workers who frequently move in and out of employment (twice or more) is particularly high in Australia, Spain, Finland, the United Kingdom, the Netherlands and Sweden (Figure 7). 
30. A high frequency of a change in status is observed for male, low educated and younger (between 25 and 45) workers (Figure 8). This fact could be linked to a more intensive use of seasonal or short-term contracts, with the undesired effects on labour market prospects and lower chances of obtaining a stable job. Low income workers, defined by the first quartile of the monthly labour income distribution of the previous year, tend to show less change in labour market status than their middle income counterparts (Figure 8). This may be linked to the fact that they experience longer unemployment and inactivity spells. Part-time workers ${ }^{3}$ could also explain the lower frequencies, since they may be in the lower part of the monthly income distribution.

Figure 8. High transition rates are observed for male, low education and young workers
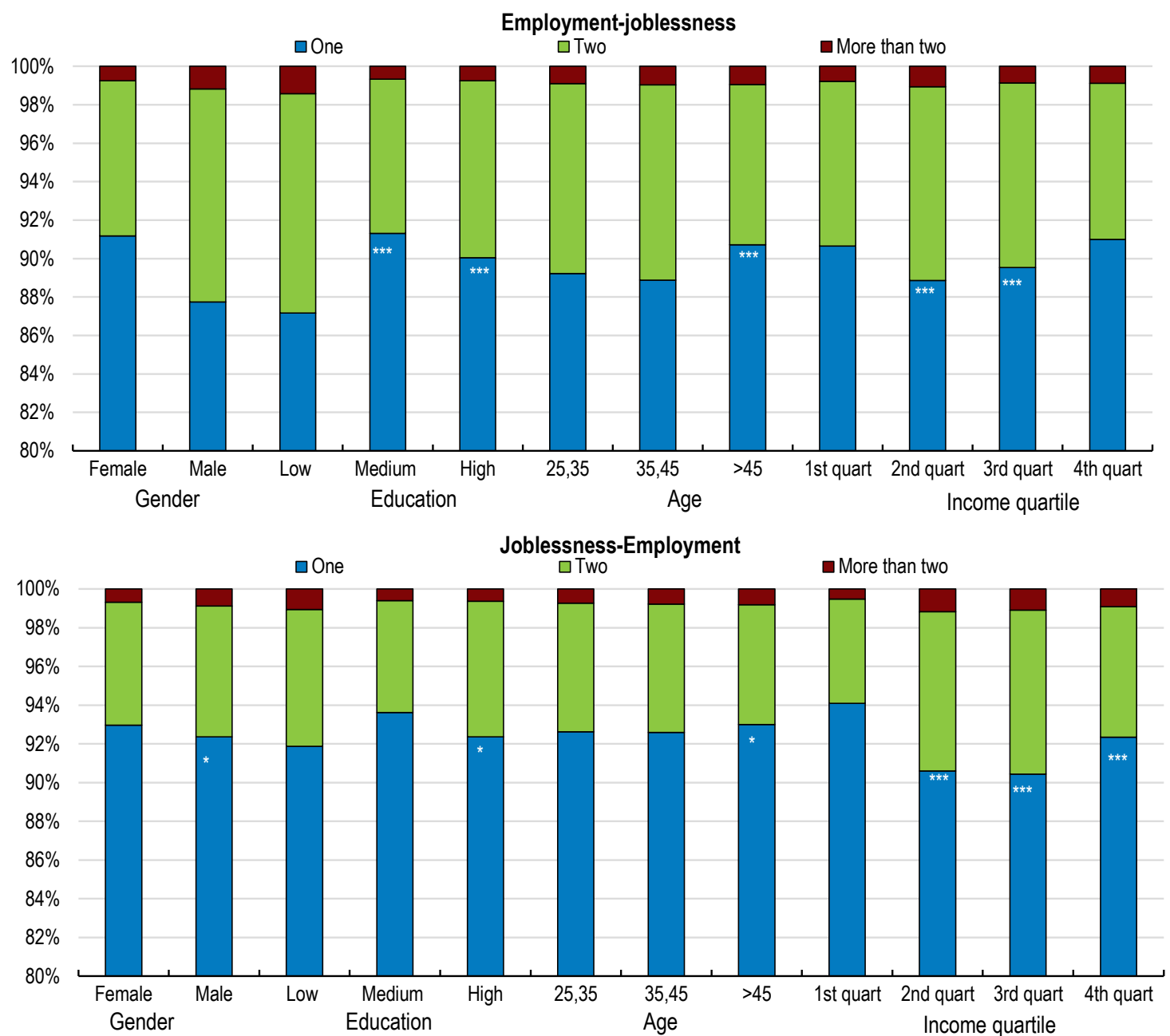

Note: Averages based on weighted sample for the period 2005-12 or latest available year. Medium education is high school, while low and high education are less and more than high-school, respectively. Income quartile refers to last year's average monthly labour income. Stars indicate, if the proportion of workers doing one change during the years is significantly different from the reference group (female, low educated, aged between 25 and 35, and first income quartile). ${ }^{\star * *}$ indicates significance at the $1 \%$ level, ${ }^{\star *}$ at the $5 \%$ level and * at the $10 \%$ level. EU-SILC; HILDA; SHP; SOEP are used.

Source: OECD Secretariat calculations.

3. Most of the surveys contain only usual hours worked during the reference week of the survey, and hence do not belong to the income reference period. For this reason, hourly income is not used to define income quartiles. 
31. Which are the individual characteristics of the workers becoming unemployed or economically inactive after being employed the previous year, and vice versa? Figure 9 shows that female, medium educated, old and second quartile income workers account for more than $40 \%$ of the workers becoming jobless. Young or low income jobless people form the biggest sub-groups of those who become employed.

Figure 9. Who becomes jobless or employed?

\section{Percentages}
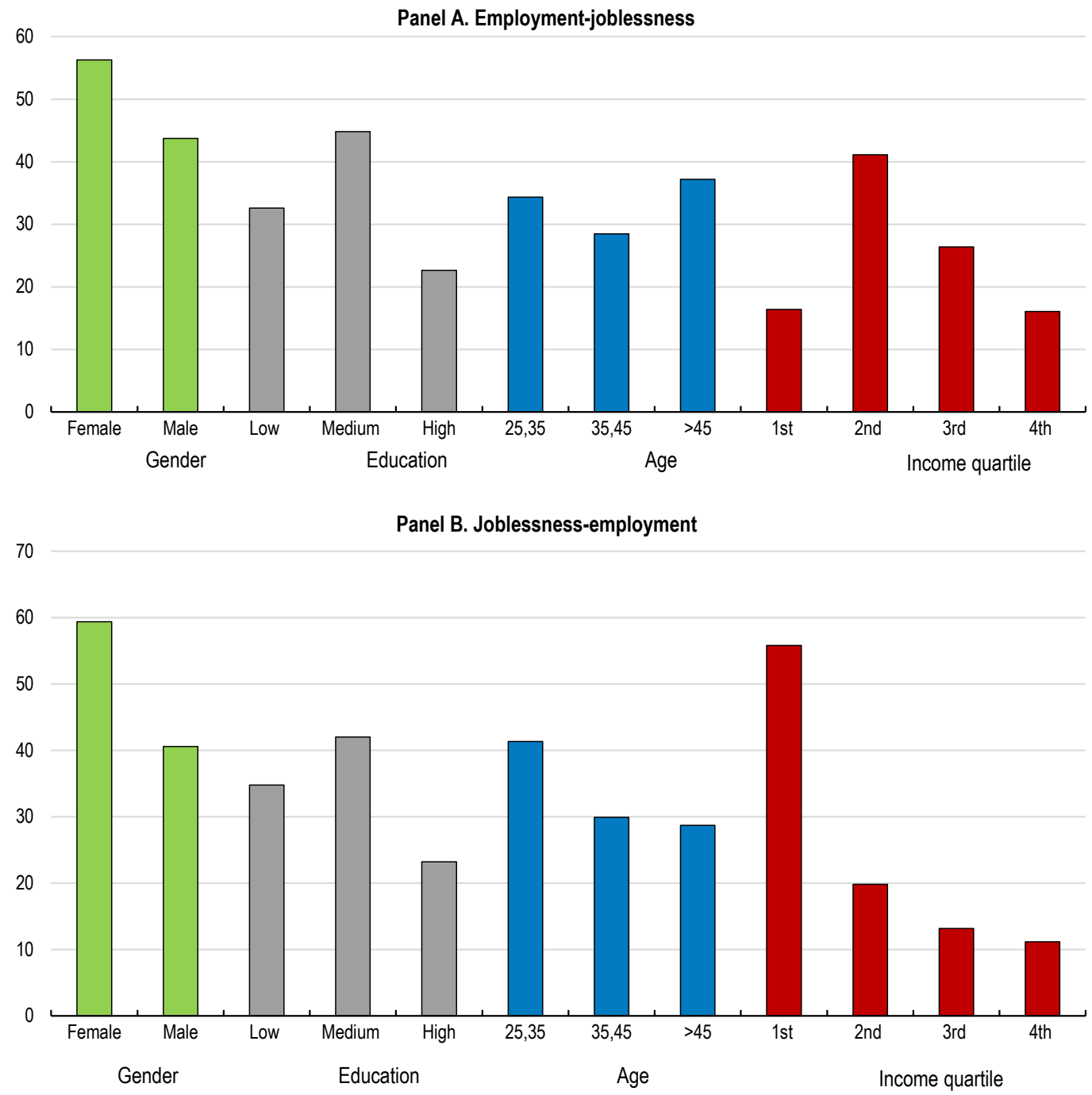

Note: Averages based on weighted sample for the period 2005-12 or latest available year. Medium education is high school, while low and high education are less and more than high school, respectively. Income quartile refers to last year's average monthly labour income in months during which the individual worked. See Table 1 for the list of covered countries. EU-SILC; HILDA; SHP; SOEP are used.

Source: OECD Secretariat calculations.

32. Figure 10 presents transition rates by socio-demographic group and worker characteristics. On average across countries in the period 2005-12, women face a $12 \%$ probability of becoming jobless after being employed in December of the previous year. For men, the probability is lower at around 8\% (Figure 10, panel A, green bars). Instead, the probability of getting employed conditional on having been jobless in December of the previous year is higher for men (37\%) than women (25\%) (Figure 10, panel B, green bars). 
Figure 10. Transition probabilities by individual characteristics

Percentages

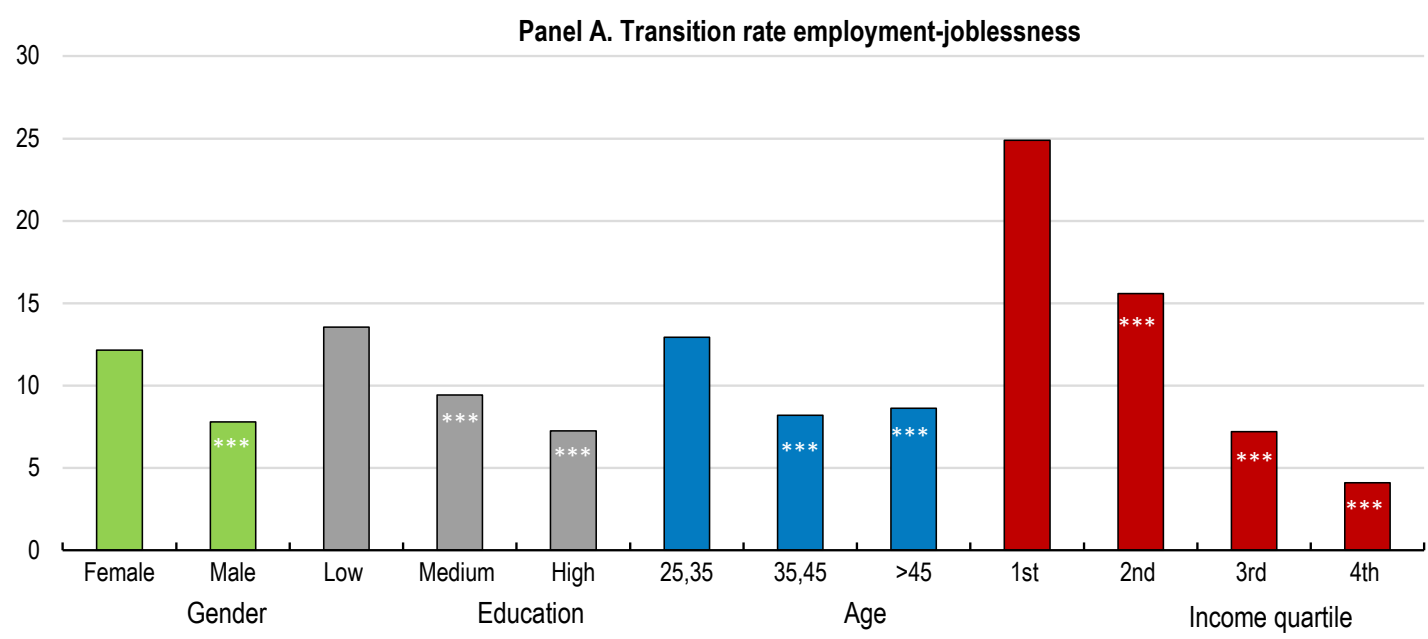

Panel B. Transition rate joblessness-employment

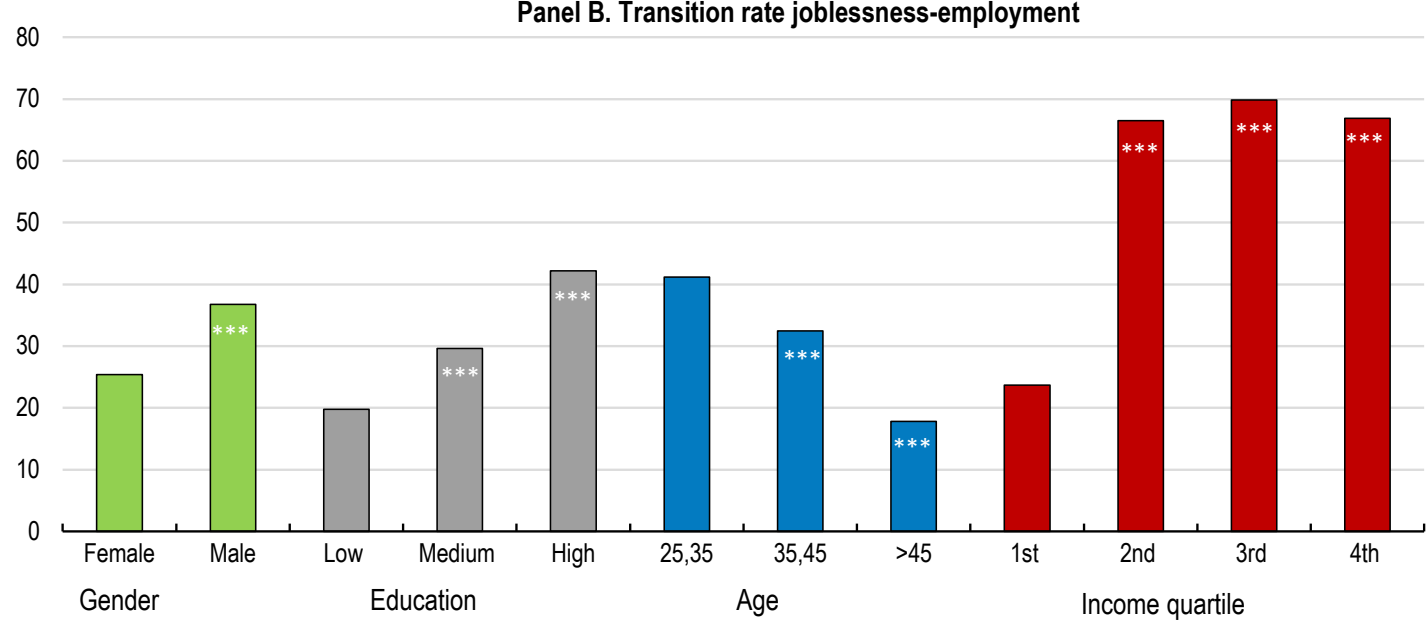

Note: Average based on weighted sample for the period 2005-12 or latest available year. Medium education is high school, while low and high education are less and more than high school, respectively. Income quartile is defined as last year's average monthly labour income. Stars indicate if the proportion of workers is significantly different from the reference group (female, low educated, aged between 25 and 35, and first income quartile). ${ }^{* *}$ indicates significance at the $1 \%$ level, ${ }^{* *}$ at the $5 \%$ level and ${ }^{*}$ at the $10 \%$ level. See Table 1 for the list of covered countries. EU-SILC; HILDA; SHP; SOEP are used.

Source: OECD Secretariat calculations.

33. The difference between men and women stems primarily from transitions into inactivity rather than unemployment. Decomposing the probability of becoming jobless into becoming unemployed and being out of the labour force conditional on having been employed in December of the previous year, it can be seen that the asymmetry between men and women comes from a four times higher probability for women to become economically inactive than for men, while the probability of becoming unemployed is similar (Figure 11). This fact is probably partly related to a voluntary choice of women associated with motherhood and child care. 
ECO/WKP(2016)74

Figure 11. Women are nearly four times more likely than men to become economically inactive

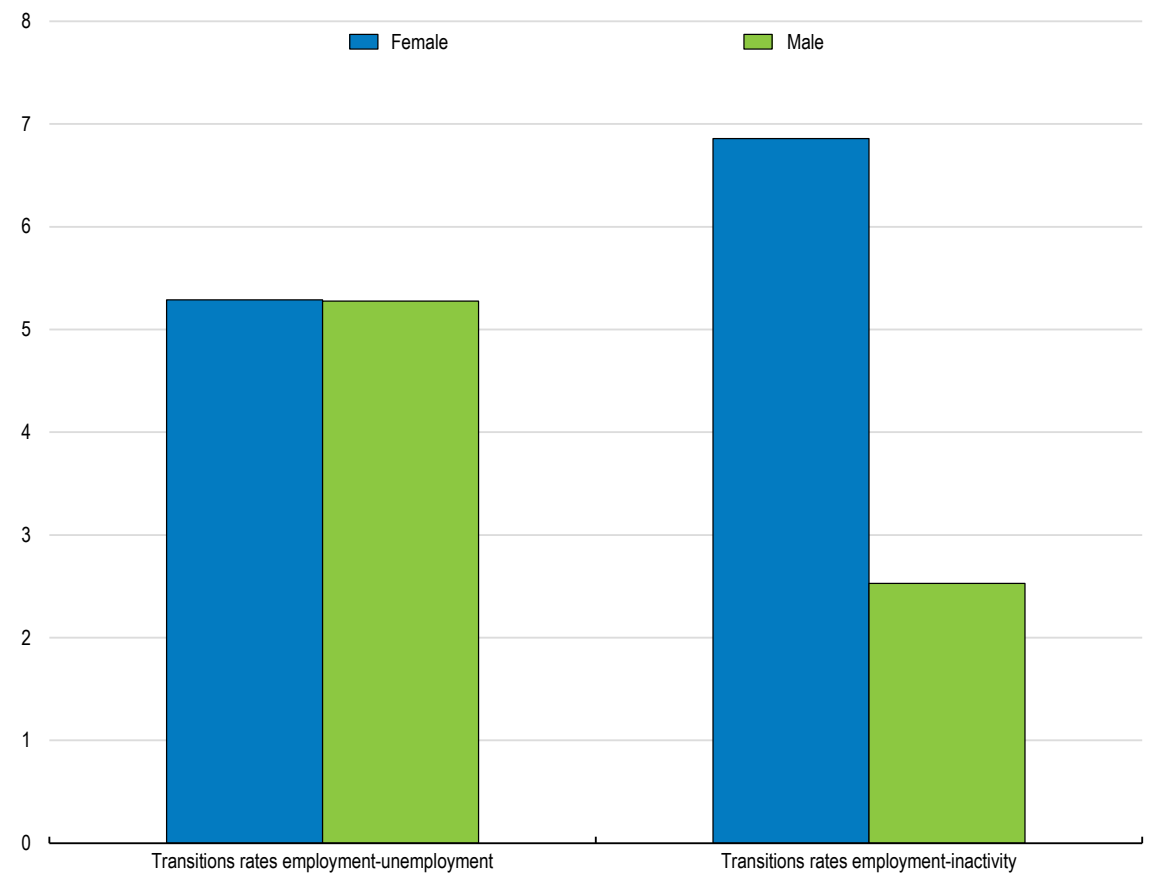

Note: Averages based on weighted sample for the period 2005-12 or latest available year. See Table 1 for the list of covered countries. EU-SILC; HILDA; SHP; SOEP are used.

Source: OECD Secretariat calculations.

34. Young workers face higher probabilities of becoming unemployed or inactive than their counterparts (Figure 10, panel A), while once jobless they have a higher probability of being re-employed (Figure 10, panel B). This could be related to young workers being more flexible and in search of a better labour market match. However, it can also be linked to low firm retention rates of younger workers and a higher use of fixed-term contracts.

35. Low educated workers face higher risks of becoming unemployed or being out of the labour force than higher educated ones (Figure 10, panel A). This twice higher probability comes with a much lower probability that jobless, low-educated workers become employed when compared with workers with a higher educational attainment (Figure 10, panel A).

36. Workers coming from the lowest part of the labour income distribution suffer the highest transition rates from employment to joblessness (Figure 10, panel A) and the lowest ones in the other direction (Figure 10, panel B). Workers with no employment in the previous December have a very low probability of becoming employed, since some of them are already out of the labour force (Figure 10).

37. Female, low educated and low income workers have the highest risk of becoming jobless (Figure 10). Once jobless, this group of workers experiences a lower probability of moving into a job. The size of these differences is rather large, implying that lacking education or being female alone can increase one's labour market insecurity several times relative to their (highly-educated or male) peers. Lower wellbeing associated with unemployment, and the economic insecurity due to unemployment is not entirely caused by the loss of a job per se, but it is intensified by the frequency and duration of consecutive unemployment spells and their consequences in terms of earnings losses (Jacobson et al., 1993). 


\section{Transition probabilities and the institutional framework}

38. The large cross-country variation in the ins and outs of employment suggests that national policies and institutions may play a role in shaping the patterns of worker flows in OECD countries. The companion paper by Cournède, Denk and Garda (2016) applies econometric techniques using crosscountry/time identification to analyse the impact of flexibility-enhancing reforms on the transition probabilities. Instead, the aim of this section is to provide a simple descriptive cross-country analysis.

39. Figure 12 shows standardised policy indicators for high and low transition probability countries. Countries have been separated into low and high transition probability countries using $\lambda_{\mathrm{LE}}$ and $\lambda_{\mathrm{EL}}$. High transition probability countries have on average a transition probability into employment of $30 \%$, while an average transition probability out of employment that averages $10 \%$. For low transition probability countries, these figures are $21 \%$ and $8 \%$.

Figure 12. Policies differ between countries with high and low transition probabilities

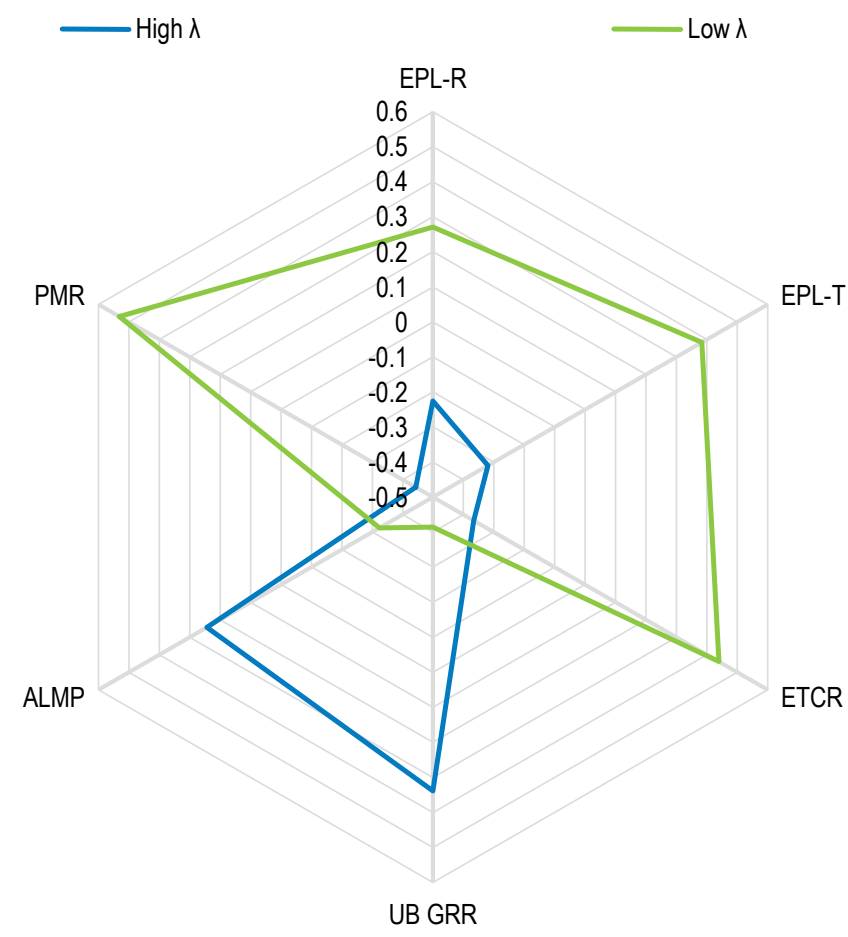

Note: Countries have been separated in two groups depending on their transition probabilities. Low transition probability countries are BEL, CZE, DEU, FRA, GRC, ITA, LUX, POL, SVK and SVN and high transition probability countries are AUS, AUT, CHE, DNK, ESP, EST, GBR, HUN, IRL, NLD, NOR and PRT. The indicators are standardised to have OECD-wide zero mean and a standard deviation of one. Zero indicates the average across the OECD countries considered. An indicator above zero means the variable is above the average, while below zero means it is below the average. EPL-R is the OECD indicator of the strictness of employment protection for regular contracts and EPL-T for workers with a fixed-term contract. PMR is the OECD product market regulation indicator. ETCR stands for the OECD Indicator of Energy, Transportation and Communication index. ALMP (Active Labour Market Policies) is spending on active labour market policies per unemployed as a percentage of GDP per capita. UB GRR is the unemployment benefit gross replacement rate (unemployment benefit over previous wage). EU-SILC; HILDA; SHP; SOEP, OECD Employment Database; OECD Product Market Regulation database and OECD Economic Outlook database are used.

Source: OECD Secretariat calculations. 
40. Regulatory constraints seem to be associated with different employment transition probabilities. Countries with more rigid labour markets are characterised by low transition probabilities (Figure 12). In the presence of dismissal restrictions, both for regular or fixed term contracts, firms have an incentive to reduce hirings and separations, because they increase the expected cost of future lay-offs imposing implicit and explicit costs on a firm's ability to adjust its workforce (Mortensen and Pissarides, 1994). This is in line with recent research that has found that overly strict regulations for permanent contracts reduce job flows (Cingano et al., 2010; Haltiwanger et al., 2013 and OECD, 2010; 2013), even if the impact on employment or unemployment levels is insignificant (Gal and Theising, 2015; OECD, 2006). Bassanini and Garnero (2013) show that the more restrictive employment regulations are, the lower is the rate of within-industry job-to-job transitions, while no significant effect is detected as regards job-to-job transitions involving an industry change and/or job-to-jobless transitions. The companion paper (Cournède, Denk and Garda, 2016) finds no significant impact of labour market regulations on transition probabilities in the long term.

41. Countries with more competitive product markets generally have higher rates of labour-market transitions (Figure 12). Anti-competitive regulations in product markets, such as a high cost for creating a business, reduce both entry and exit of firms (Andrews and Cingano, 2014). Since firm entry and exit explain about one third of the worker flows through new hirings and staff cuts (OECD, 2010; Criscuolo et al., 2014), product market regulation can have an important impact on transition probabilities. There is little evidence on the impact of anti-competitive regulation on job flows, except for the findings in OECD (2010). This study showed that industries that have been liberalised increased separations and hirings, but the estimated effect is small. The companion paper (Cournède, Denk and Garda, 2016) shows that making product market regulation more pro-competitive leads to higher job finding rates and has no significant impact on the probability of becoming unemployed or leaving the labour force.

42. Unemployment benefit generosity appears to be linked with high rates of labour market transitions (Figure 12). Theoretically, generous unemployment benefits, by reducing search effort, may increase the duration of unemployment and the overall level of unemployment (see OECD, 2010, for a survey of the literature of the different channels through which unemployment benefits may affect gross flows), which will tend to slow the transitions from unemployment to employment. Consistent with the microeconometric literature, generous unemployment benefits tend to increase job-to-unemployment transitions (Dormont et al., 2001). A European cross-country/firm-level/time-series analysis yielded a negative association of average gross replacement rates with employment-unemployment transitions (Boeri and Garibaldi, 2009; Gomez-Salvador et al., 2004). However, industry-level evidence shows that unemployment benefit generosity appears to have a positive impact on average gross worker flows (OECD, 2010).

43. Active labour market programmes (ALMP) are designed to help workers find jobs and shorten unemployment duration (Card et al., 2010). Countries with high spending on ALMPs have high transition probabilities (Figure 12), mainly explained by a high jobless-employment transition probability. Research using micro-econometric techniques shows that help given to job seekers and mandatory participation in ALMPs reduces the duration of unemployment (see Boeri et al., 2015 for a survey of the literature on job search assistance and its impact). Cross-country econometric studies find that ALMP spending reduces unemployment inflows (Murtin and de Serres, 2013) while increasing job finding rates (De Serres and Murtin, 2014). Moreover, strong job-search requirements have been identified as effective in shortening unemployment spells (Martin, 2014; Pareliussen, 2014). 


\section{REFERENCES}

Andrews, D. and F. Cingano (2014), "Public Policy and Resource Allocation: Evidence from Firms in OECD Countries", Economic Policy, 29(78), pp.253-296.

Bassanini, A. and A. Garnero (2013), "Dismissal Protection and Worker Flows in OECD Countries: Evidence from Cross-Country/Cross-Industry Data”, Labour Economics, Vol. 21, pp. 25-41.

Bassanini, A. and R. Duval (2006), "Employment Patterns in OECD Countries: Re-assessing the Role of Policies and Institutions", OECD Economics Department Working Papers, No. 486, OECD Publishing, Paris.

Bassanini, A., A. Garnero, P. Marianna and S.J. Martin (2010), "Institutional Determinants of Worker Flows: A Cross-Country/Cross-Industry Approach", OECD Social, Employment and Migration Working Papers, No. 107, OECD Publishing, Paris.

Bassanini, A., and R. Duval (2009), "Unemployment, Institutions, and Reform Complementarities: ReAssessing the Aggregate Evidence for OECD Countries", Oxford Review of Economic Policy, 25(1), pp. $40-59$.

Boeri, T. and P. Garibaldi (2009), "Beyond Eurosclerosis”, Economic Policy, Vol. 58.

Boeri, T., P. Cahuc and A. Zylberberg (2015), "The Costs of Flexibility-Enhancing Structural Reforms: A Literature Review”, OECD Economics Department Working Papers, No. 1227, OECD Publishing, Paris.

Brandolini, A. and E. Viviano (2014), "Behind and beyond the (Headcount) Employment Rate", Economic Working Papers, No. 965, Bank of Italy, Economic Research and International Relations Area.

Card D., J. Kluve and A. Weber (2010), "Active Labour Market Policies: A Meta-Analysis", Economic Journal, Vol. 120, pp. F452-F477.

Cingano, F., M. Leonardi, J. Messina and G. Pica (2010), "The Effects of Employment Protection Legislation and Financial Market Imperfections on Investment: Evidence from a Firm-Level Panel of EU Countries", Economic Policy, Vol. 61, pp. 117-163.

Couch, K. and D. Placzek (2010), "Earnings Losses of Displaced Workers Revisited", The American Economic Review, Vol. 100(1), pp. 572-589.

Cournède, B., O. Denk, P. Garda and P. Hoeller (2016a), "Enhancing Economic Flexibility: What Is in it for Workers?", OECD Economic Policy Papers, No. 19, OECD Publishing, Paris.

Cournède, B., O. Denk and P. Garda (2016b), "Effects of Flexibility-Enhancing Reforms on Employment Transitions", OECD Economics Department Working Papers, No. 1350, OECD Publishing, Paris. 
Criscuolo, C., P. Gal and C. Menon (2014), "The Dynamics of Employment Growth: New Evidence from 18 Countries", OECD Science, Technology and Industry Policy Papers, No. 14, OECD Publishing, Paris.

Davis S. and T. von Wachter (2011), "Recessions and the Costs of Job Loss", Brookings Papers on Economic Activity, Economic Studies Program, The Brookings Institution, Vol. 43(2), pp. 1-72.

Denk, O. (2016), "How Do Product Market Regulations Affect Workers? Evidence from the Network Industries", OECD Economics Department Working Papers, No. 1349, OECD Publishing, Paris.

De Serres, A. and F. Murtin (2014), "Unemployment at Risk: the Policy Determinants of Labour Market Exposure to Economic Shocks", Economic Policy, Vol. 29(80), pp. 603-637.

Dormont, B., D. Fougère, D. and A. Prieto, A. (2001), "The Effect of the Time Profile of Unemployment Insurance Benefits on Exit from Unemployment", CREST Working Paper, Paris.

Gal, P. and A. Theising (2015), "The Macroeconomic Impact of Policies on Labour Market Outcomes in OECD Countries: a Re-assessment", OECD Economics Department Working Papers, No. 1271, OECD Publishing, OECD.

Gomez-Salvador, R., J. Messina and G. Vallanti (2004), "Gross Job Flows and Institutions in Europe", Labour Economics, Vol. 11, pp. 469-485.

Haltiwanger, J. C., H. R. Hyatt and E. McEntarfer (2015), "Cyclical Reallocation of Workers across Employers by Firm Size and Firm Wage”, NBER Working Paper, No. 21235.

Haltiwanger, J., S. Scarpetta and H. Schweiger (2013), "Cross Country Differences in Job Reallocation: The Role of Industry, Firm Size and Regulations", Labour Economics, Vol. 26, Pages 11-25.

Hijzen, A. and B. Menyhert (2016), "Measuring Labour Market Security and Assessing its Implications for Individual Well-Being", OECD Social, Employment and Migration Working Papers, No. 175, OECD Publishing, Paris.

Jacobson, L. S., R. J. LaLonde and D. G. Sullivan (1993), “Earnings Losses of Displaced Workers”, American Economic Review, Vol. 83, No. 4, pp. 685-709.

Martin, J. (2014), "Activation and Active Labour Market Policies in OECD Countries: Stylised Facts and Evidence on their Effectiveness", IZA Policy Paper, No. 84.

Murtin, F. and A. de Serres (2013), "How do Labour Market Institutions Affect the Exit Rate out of Unemployment?", OECD Economics Department Working Papers, OECD Publishing, Paris.

Murtin, F., A. de Serres and A. Hijzen (2014), "Unemployment and the Coverage Extension of Collective Wage Agreements", European Economic Review, Vol. 71, pp. 52-66.

OECD (2010), "Institutional and Policy Determinants of Labour Market Flows", in: OECD Employment Outlook 2010: Moving beyond the Jobs Crisis, OECD Publishing, Paris.

OECD (2009), "How Do Industry, Firm and Worker Characteristics Shape Job and Worker Flows?", in OECD, OECD Employment Outlook 2009: Tackling the Jobs Crisis, OECD Publishing, Paris.

OECD (2006), OECD Employment Outlook 2006: Boosting Jobs and Incomes, OECD Publishing, Paris. 
Pareliussen, J. (2014), “Overcoming Vulnerabilities of Unemployment Insurance Schemes," OECD Economics Department Working Papers, No. 1131, OECD Publishing, Paris.

Sullivan, D. and T. von Wachter (2009), "Job Displacement and Mortality: An Analysis Using Administrative Data", The Quarterly Journal of Economics, Vol. 124(3), Pages 1265-1306.

Venn, D. (2011), "Earnings Volatility and its Consequences for Households", OECD Social, Employment and Migration Working Papers, No. 125, OECD Publishing, Paris. 